\title{
KAJIAN TENTANG POTENSI DAYA TARIK WISATA SYARIAH DI PULAU LOMBOK
}

\author{
Oleh \\ Rozita $^{1}$, Andi suprianto ${ }^{2}$, Mahdani $^{3}$, Lalu Masyhudi $^{4}$, Rizal Kurniansah $^{5)}$ \\ 1,2,3,4,5Sekolah Tinggi Parwisata Mataram \\ Email: ${ }^{1}$ roziita0808@gmail.com,${ }^{4}$ laloemipa@gmail.com \& ${ }^{5}$ rizalsstpar@yahoo.com
}

\begin{abstract}
Abstrak
Wisata syariah adalah wisata yang mengedepankan nilai islam dalam setiap aktivitasnya, wisata syariah itu sendiri memiliki arti yang lebih luas yaitu pariwisata yang keseluruhannya tidak bertentangan dengan syariah islam misalkan keberadaan hotel, restoran, trasnportasi, fasilitas ibadah dan obyek wisata itu sendiri yang tidak bertentangan dengan syariah islam. Pulau Lombok sendiri memiliki potensi untuk dijadikan destinasi wisata syariah di Indonesia. Pada tahun 2015, Lombok pernah meraih 2 penghargaan yaitu best World Halal Tourism Destination dan World Best Halal Honeymoon Destination. Kedua penghargaan tersebut menjadi bukti, bahwa pulau Lombok memang menjadi primadona bagi para wisatawan untuk berlibur di Lombok. Pengembangan pariwisata di pulau Lombok masih terfokuskan pada pengembangan pariwisata alam dan budayannya. Sedangkan wisata Syariah belum terlalu berkembang secara maksimal sedangkan potensi untuk dikembangkannya wisata Syariah di pulau Lombok cukup terbuka.Penelitian ini bertujuan untuk mendeskripsikan potensi daya tarik wisata syariah di pulau lombok dan mendeskripsikan ketersediaan komponen produk pendukung wisata syariah di pulau Lombok. Teknik pengumpulan data yang digunakan yaitu observasi, wawancara, studi pustaka dan dokumentasi. Sedangkan analisis data yang digunakan yaitu analasis data deskriptif kualitatif. Berdasarkan hasil penelitian yang dilakukan yaitu potensi daya tarik wisata syariah di pulau Lombok telah tersedia antara lain Makam Bintaro, Masjid Islamic Center, Pantai tanjung karang, Festival Ngejot, Acara Adat Tiu Jantuk, Makam Selaparang dan Masjid Bayan Beleq, Upacara Adat Ngayu-ayu. Sedangkan ketersediaan komponen produk pendukung wisata syariah di pulau telah tersedia meskipun masih perlu ditingkatkan lagi keberadaannya. Adapun komponen pendukung tersebut antara lain hotel syariah (Hotel Grand Madani Lombok), Kondisi Jalan sudah baik, dan didukung pelayanan taksi konvensi dan online yaitu Gojek dan Grab. Serta pelayanan pendukung yang terorganisasi seperti Dinas Pariwisata Kabupaten Lombok Utara, Mataram, Lombok Tengah, Lombok Timur dan Lombok Barat dengan berkoordinasi dengan Dinas Pariwisata Provinsi NTB. Peran lain dari pemerintah yaitu mengupayakan disetiap daya tarik wisata syariah di suatu desa membentuk salah satu kelompok sadar wisata (Pokdarwis) untuk mengelola daya tarik wisata syariah di desa masing-masing.
\end{abstract}

Kata Kunci: Potensi, Daya Tarik Wisata, Syariah \& Lombok

\section{PENDAHUALUAN}

Lombok telah dikenal oleh banyak orang sebagai pulau seribu masjid, sebutan pulau Lombok sebagai pulau seribu masjid sebenarnya diambil dari ucapan seorang Dirjen Bimas Islam Kementerian Agama Republik Indonesia yaitu Bapak Effendi Zarkasih. Pada tahun 1970, beliau meresmikan masjid Jami yang berlokasi di kecamatan cakranegara mataram, dengan melihat banyaknya masjid di pulau Lombok, Bapak Effendi memberikan julukan pulau seribu masjid. http://ejurnal.binawakya.or.id/index.php/MBI

Open Journal Systems
Sampai sekarang, julukan tersebut telah dikenal banyak masyarakat di Indonesia.

Keberadaan masjid di pulau Lombok tidak semata-mata digunakan sebagai tempat ibadah, tetapi di gunakan sebagai tempat berjiarah karena terdapat makam-makam para pemuka agama serta sebagai tempat berwisata di beberapa masjid-masjid tua yang dibangun pada masa lampau. Keberadaan masjid-masjid di Lombok tentu di dukung oleh kehidupan bermasyarakat yang islami. Selain itu, Lombok

Vol.13 No.12 Juli 2019 
juga memiliki daya tarik yang mampu menarik para masyarakat luar untuk berkunjung di palau lombok yaitu daya tarik wisata alam yang sangat indah. Keberadaan daya tarik wisata alam tersebut tentu dapat mendukung jalannya aktifitas wisata yang saat ini masih baru di kenal di Indonesia yaitu wisata Syariah atau halal tourism.

Wisata syariah adalah wisata yang mengedepankan nilai islam dalam setiap aktivitasnya. Wisata syariah itu sendiri memiliki arti yang lebih luas yaitu pariwisata yang keseluruhannya tidak bertentangan dengan syariah islam misalkan keberadaan hotel, restoran, trasnportasi, fasilitas ibadah dan obyek wisata itu sendiri yang tidak bertentangan dengan syariah islam.

Pulau Lombok sendiri memiliki potensi untuk dijadikan destinasi wisata syariah di Indonesia. Pada tahun 2015, Lombok pernah meraih 2 penghargaan yaitu best World Halal Tourism Destination dan World Best Halal Honeymoon Destination. Kedua penghargaan tersebut menjadi bukti, bahwa pulau Lombok memang menjadi primadona bagi para wisatawan untuk berlibur di Lombok. Selain memberikan kemudahan bagi para wisatawan muslim untuk beribadah dan menikmati makanan dan minuman yang halal, pulau Lombok pun menyediakan keindahan alam dan keunikan budaya yang beragam. Pengembangan pariwisata di pulau Lombok masih terfokuskan pada pengembangan pariwisata alam dan budayannya. Sedangkan wisata Syariah belum terlalu berkembang secara maksimal, potensi untuk dikembangkannya wisata Syariah di pualu Lombok cukup terbuka. Karena masyarakat yang mayoritas muslim, banyaknya masjid-masjid bersejarah dan modern serta ditetapkannya brand halal tourism menjadi peluang tersendiri bagi pulau Lombok untuk menjadi salah satu destinasi pariwisata Syariah di Indonesia.

\section{Metode Penelitian}

Wisata syariah adalah wisata yang mengedepankan nilai islam dalam setiap aktivitasnya. Istilah wisata Syariah sebanarnya telah dikenal di beberapa negara dengan istilah yang berbeda-beda, istilah-istilah tersebut antara lain Islamic tourism, halal tourism, halal travel dan as moslem friendly destination. Menurut Kemenpar (2012), mengemukakan bahwa pariwisata syariah kegiatan yang didukung oleh berbagai fasilitas serta layanan yang disediakan masyarakat, pengusaha, pemerintah, dan pemerintah daerah yang memenuhi ketentuan Syariah.

Lebih lanjut tim peneliti bidang pengembagan kelembagaan kepariwisata kementerian pariwisata (2015) mengemukakan bahwa wisata syariah adalah wisata yang didalamnya berasal dari alam, budaya, ataupun buatan yang dibingkai dengan nilai-nilai islam dimana kegiatannya didukung oleh berbagai fasilitas serta layanan (hotel, restoran, biro perjalanan dan spa) yang disediakan masyarakat, pengusaha, pemerintah yang memenuhi ketentuan syariah islam.

Yoeti (2002) mengemukakan bahwa keberhasilan suatu tempat wisata hingga tercapainnya kawasan wisata sangat tergantung pada 3A yaitu atraksi (Attraction), mudah dicapai (Accessibilty), dan fasilitas (Amenities). Kurniansah (2018) mengemukakan bahwa Selain potensi yang sudah lengkap, keberadaan sarana pendukung yaitu fasilitas-fasilitas penunjang pariwisata seperti hotel dan restoran yang memadai dan dapat memberikan pelayanan yang maksimal kepada wisatawan.

Jenis penelitian ini adalah penelitian kualitatif, metode pengumpulan data yaitu observasi (pengamatan langsung), wawancara, studi pustaka, dan dokumentasi. Analisis data dalam penelitian ini yaitu analisis data deskriptif kualitatif.

HASIL DAN PEMBAHASAN

Potensi Daya Tarik Wisata Syariah di Pulau Lombok

A. Taman Makam Bintaro

http://ejurnal.binawakya.or.id/index.php/MBI 
Makam Bintaro merupakan tempat pemakaman Habib Husein Bin Umar Mashur, Syarifah Zahra Al Habsy, dan Syech Abdullah Al Badawi yang sebelumnya singgah di Malaysia setelah meninggalkan Hadramaut di Yaman Selatan. Makan Bintaro ini berlokasi di Jl. Saleh Sungkar, Bintaro, Ampenan, Kota Mataram, NTB. 83118. Sekitar tahun 1865 beliau tiba di Lombok dengan membawa misi untuk menyempurnakan agama islam yang telah disebarkan beberapa puluh tahun sebelumnya. Karena ajaran masih dengan kondisi tercampur dengan tradisi bahkan mengarah pada penyimpangan-penyimpangan. Sehingga, beliau tinggal dan menetap di Lingkungan Telaga Mas, Kampung Arab, Ampenan dan wafat sekitar tahun 1880.

Luas Makam Bintaro ini lebih kurang 4,5 hektar, dan makam para Habib ini berada disebuah bangunan yang berwarna kuning. Dimana makamnya dibuat paling besar dan diberi kain penutup. Juga terdapat 21 makam lainnya atau dapat disebut 21 pengikut Habib.

Berdasarkan hasil wawancara dengan Bapak Salim yang merupakan penjaga Makam Bintaro menuturkan bahwa Habib Husein Bin Umar Mashur dan Syarifah Zahra Al Habsy merupakan pasangan suami istri. "Jadi, ini dia makamnya yang berderet, sedangkan makam Syech Abdullah Al Badawi hanya sendiri”. Ungkapnya, Minggu (14/04/2019).

Lebih lanjut Bapak Salim menuturkan bahwa Syech Abdullah Al Badawi berasal dari Malaysia. "jadi Syech Abdullah Al Badawi berasal dari Malaysia sedangkan, Habib Husein Bin Umar Mashur dan istrinya berasal dari Yaman". Jelasnya.

Makam Bintaro ini dapat dikunjungi setiap harinya. Tetapi paling ramai setiap hari minggu dan sejauh ini pengunjungyang datang untuk berjiarah di makam ini yaitu dari seluruh Pulau Lombok. Makam Bintaro yang merupakan salah satu objek wisata tentu saja tidak ingin kalah saing dengan objek wisata lainnya dalam hal akomodasi. Fasilitas penunjangnya yaitu, tersedianya MCK, musholla, berugak, kantor sekretariat, dan area parkir yang cukup luas.
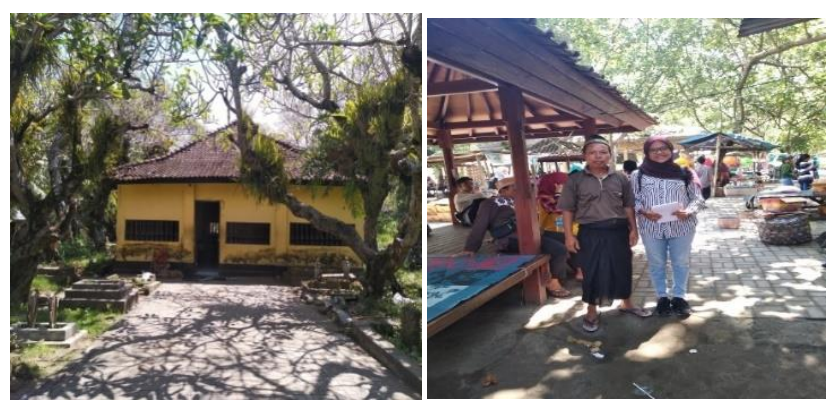

Gambar : Taman Makam Bintaro

\section{B. Masjid Islamic Center}

Masjid Islamic Center yang berlokasi di j1. Udayana, Dasan Agung, Selaparang, Gomong, Kota Mataram, NTB. 83125 merupakan objek wisata religi. Masjid ini diresmikan pada tanggal 15 desember 2013. Masjid ini dikelola oleh Badan Pengelolaan dan Aset Daerah (BPKAD) Unit Pengelola Islamic Center NTB. Bapak Sulaiman Jamsuri, S.Ag, MAP. selaku Kepala Unit Pengelolaan Islamic Center. Beliau menuturkan bahwa pada tahun 2017 Masjid ini mencapai target pariwisata dengan tingkat kunjungan ke-2 dari Rinjani.

Masjid yang banyak dikunjungi oleh wisatawan lokal maupun mancanegara ini dikarenakan, Masjid Islamic Center memiliki banyak spot photo yang begitu menarik serta arsitektur dari bangunannya begitu indah nan mewah. Bangunan masjid dengan luas lebih kurang 7,5 hektar ini memiliki fasilitas penunjang yaitu, area parkir yang begitu luas, ballroom, escalator, lift, dan meeting room. Bangunan masjid yang terdiri dari empat lantai ini dilengkapi dengan menara yang menjulang tinggi sampai 99 meter yang bermakna 99 asma'ul husna. Bangunan tersebut merupakan icon dari masjid itu sendiri.

Tidak kalah menariknya, pengawas masjid, Bapak Ali, menuturkan bahwa Masjid ini memiliki SOP/Standar Operasional Prosedur yang harus diikuti oleh semua wisatawan yaitu, wisatawan non-muslim diharuskan menggunakan pakaian muslim ketika hendak memasuki Masjid. Dan ternyata pakaian muslim itu pun sudah disiapkan langsung di Masjid. "Masjid ini harus benar-benar kita jaga kesuciannya. Maka dari itu kami menerapkan SOP bagi wisatawan non-

Vol.13 No.12 Juli 2019 
muslim untuk menggunakan pakaian muslim ketika hendak memasuki Masjid. Dan tidak perlu khawatir, karena pakaian muslim sudah kami sediakan di Masjid”. Jelas, Pak Ali.

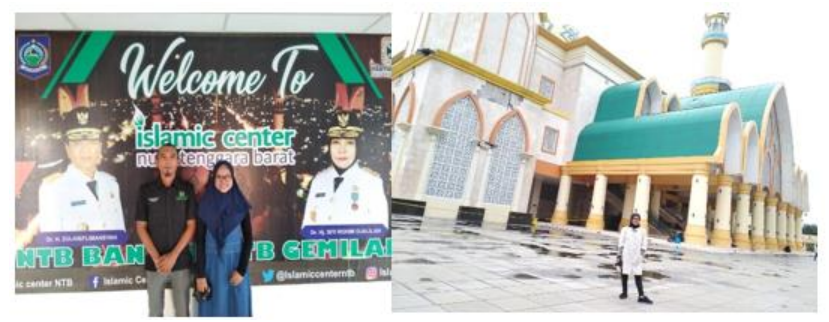

Gambar: Masjid Islamic Center

\section{Pantai Tanjung Karang}

Pantai tanjung karang berlokasi di jln. Sultan Kaharudin, Pagesangan, Kec. Mataram, Kota Mataram, NTB. 83115 ini sudah ada sejak zaman dahulu kala sebelum adanya Pantai Loang Baloq dan Pantai Gading. Pantai tersebut dikelola oleh warga setempat dan dikenal dengan kebersihan serta keramah tamahan warga setempat. Hal ini yang menjadikannya sebagai objek wisata yang banyak dikunjungi oleh wisatawan lokal dan non lokal.

Pak H. Multazam, Kepala Lingkungan sekaligus penanggungjawab objek wisata tersebut menuturkan bahwa pantai tersebut sudah dikenal oleh banyak orang bahkan, pejabat tinggi sekalipun.

"Dikarenakan pantai ini sudah ada sejak zaman dahulu kala, maka pantai ini sangat terkenal dikalangan masyarakat, pemerintah, dan pejabat-pejabat tinggi lainnya. Bahkan pemerintah menganjurkan untuk selalu menjaga kebersihan dari pantai tersebut". Ungkapnya. Sabtu (18 Mei 2019). Sebagai objek wisata, tentu saja pihak pengelola dan penanggung jawab harus menjaga dan meningkatkan existensi dari pantai tersebut. Tentunya pantai ini didukung oleh fasilitas seperti berugak, tempat parkir, mushola sekaligus taman bacaan yang disahkan oleh Ibu Kapolda, dan permainan anak-anak seperti, ayunan dll.

Adapun icon utama dari pantai ini ialah, tulisan Pantai Tanjung Karang yang berdiri kokoh menjulang tinggi yang menjadikannya sebagai daya tarik tersendiri bagi wisatawan. Selain itu, kita juga dapat melihat jutaan perahu cantik milik nelayan. Hal ini pun memberikan dampak positif seperti, peningkatan perekonomian warga setempat.

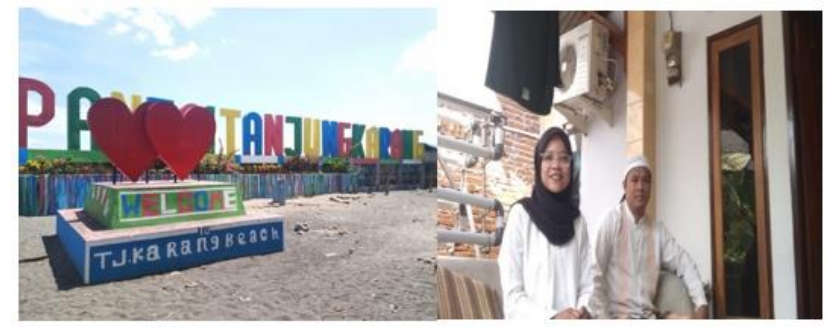

Gambar: Pantai Tanjung Karang

\section{Festival Ngejot}

Festival Ngejot merupakan adat tradisi budaya masyarakat Desa Lenek yang dilakukan 1 hari sebelum Hari Raya Idul Fitri, dengan membawa kain atau muknah dan bermacammacam makanan serta jajanan khas Desa Lenek. Desa Lenek berada di Kecamatan Lenek Kabupaten Lombok Timur. Aturan untuk membawa makanan tersebut menggunakan sampak atau dulang, kemudian diberikan kepada orang tua, mertua, tetangga terdekat, tokok agama dan tokoh masyarakat. Tujuan dari ngejot adalah untuk memperkukuh silaturrahmi, meminta maaf kepada orang tua dan mertua. Harapan dan keyakinan di Hari Raya Idul Fitri semua bisa mendapatkan kedamain.

Ngejot pada awalnya dilakukan setelah selesai solat Hari Raya Idul Fitri, namun seiring perkembangan zaman, banyak juga masyarakat yang melakukan Ngejot pada sehari sebelum lebaran, dengan alasan supaya setelah masyarakat slesai melakukan Solat Hari Raya Idul Fitri bisa bersilaturahmi kepada keluarga atau kerabat yang jauh-jauh.kemudian dari segi teknologi dan transportasi, masyarakat sudah terpengaruhi oleh perubahan zaman yang moderen, masyarakat sekarang sudah tergolong mampu dan rata-rata masyarakat kebutuhannya bisa terpenuhi, maka itulah alasan masyarakat melakukan Ngejot pada sore hari dan malam H-1 Hari Raya Idul Fitri, karna tidak mau repot.

Festival Ngejot di jadikan sebagai wadah untuk mempertahankan kearifan lokal masyarakat Desa Lenek serta sebagai wadah 
untuk memperkenalkan adat tradisi budaya tersebut. Ngejot biasanya dilaksanakan di Lapangan Wirangabaya Desa Lenek Lombok Timur. Selain Ngejot ada juga potesi-potensi pendukungnya, Seperti : Cagar Alam dan Sanggar Seni.

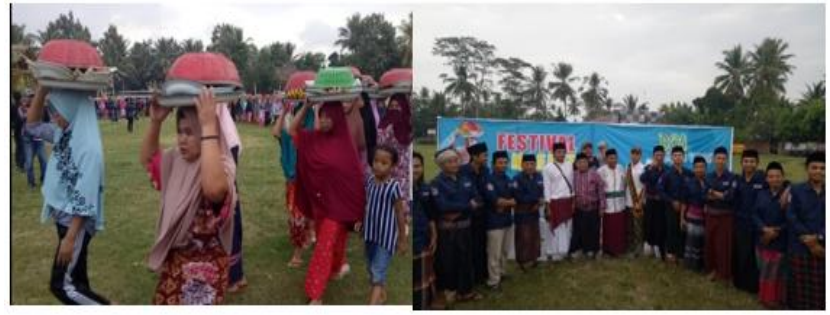

Gambar : Adat Ngejot

\section{E. Acara Adat Tiu Jantuk}

Acara Adat Tiu Jantuk adalah acara adat yang diselenggarakan Desa Jantuk, Kecamatan Sukamulia, Kabupaten Lombok Timur, Desa Jantuk memiliki atraksi budaya yang unik bernama Tiu Jantuk dan satu-satunnya acara budaya yang di tunggu-tunggu oleh mayarakat Lombok. Masyarakat Desa Jantuk baik itu anakanak maupun remaja hingga dewasa keluar memadati ke jalan untuk berkeliling-keliling di tengah-tengah desa yang ditemani kuda tunggangan dan berjalanan secara beriringan seperti pawai, kuda yang beriringan harus berjalan dengan pelan-pelan tidak boleh membawanya secara kencang-kencang.

Tradisi menunggang kuda secara ramerame merupakan peninggalan dari nenek moyang mereka, setiap warga jantuk harus memiliki kuda untuk di tunggangi. seiring perkembangan zaman, masyarakat jantuk jarang yang memiliki kuda secara pribadi. menunggangi kuda merupakan salah satu alat transportasi yang di gunakan oleh masyarakat Desa Jantuk untuk melakukan perjalanan jauh, dengan perkembangan zaman sekarang banyak masyarakatnya yang memiliki trasportasi moderen, seperti motor dan mobil. Kemajuan zaman tersebut membuat masyarakat jarang yang memiliki kuda pribadi, sehingga banyak masyarakat lebih memilih menyewa kuda untuk mengikuti acara tradisi Tiu Jantuk.

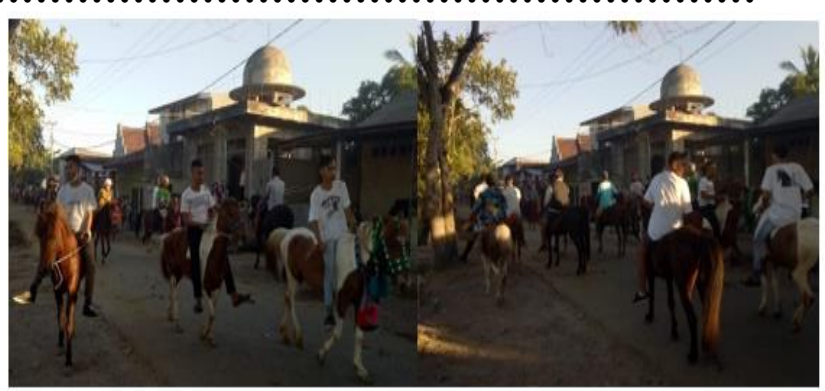

Gambar: Tiu Jantuk

Tiu Jantuk banyak mendatangkan wisatawan, baik itu wisatawan lokal bahkan wisatwan mancanegara. Masayakat mulai berjalan menunggangi kuda semenjak terbitnya matahari atau waktu setelah solat subuh hingga pukul 08:00. Tradisi tersebut membuat silaturahmi masyarakat Desa Jantuk semakin erat. Banyaknya masyakat Desa Jantuk yang tersebar di Lombok maupun keluar Lombok untuk merantau, tetapi dengan Tradisi tersebut menjadi hal yang nanti-nantikan, sehingga masyarkat yang pergi merantu akan pulang hanya untuk mengikuti acara Tiu Jantuk tersebut.

\section{F. Makam Selaparang}

Makam Selaparang terletak di Kampung Presak, Desa Selaparang, Kecamatan Pringgabaya, Kabupaten Lombok Timur (Lotim), atau sekitar 55 kilometer dari Kota Mataram membuat lokasi wisata sejarah di Lombok Timur ini dapat dijangkau dengan kendaraan bermotor jenis apapun.

Selaparang adalah tempat sejarah yang berbentuk makam atau kuburan yang dipercaya tempat hilang nya Raja selaparang dan para patihnya yang dikenal dengan nama Gajah Mada. Pada sejarahnya kerajaan selaparang pertama diduduki oleh kerajaan Hindu dan kerajaannya berakhir dengan kedatangan ekspedisi Kerajaan Majapahit pada tahun 1357. Kerajaan Selaparang kedua adalah kerajaan islam. Dalam sejarah, kerajaan selaparang tergolong kerajaan yang tangguh, baik armada laut dan daratnya. Laskar lautnya pernah diceritakan mengusir belanda yang hendak memasuki wilayah tersebut sekitar tahun 1667-1668 masehi. Kerajaan selaparang pernah dua kali terlibat dalam peperangan atau 
pertempuran melawan kerajaan Gelgel, sekitar tahun 1616 dan 1624 Masehi.

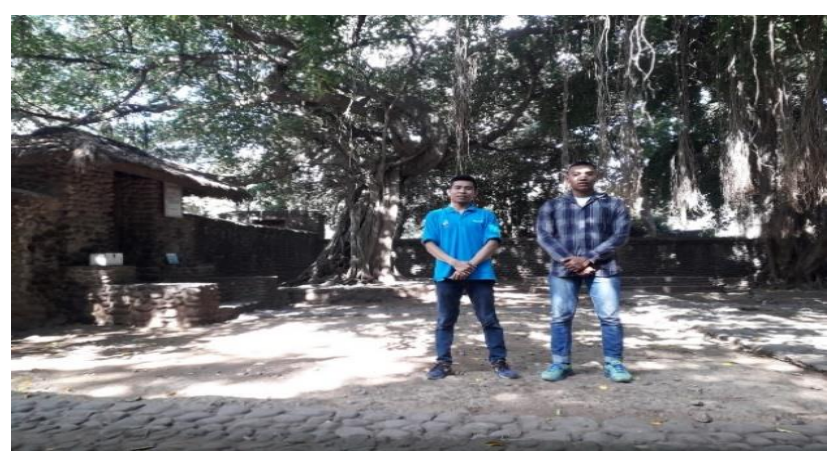

Gambar : Makam Selaparang

Selaparang juga merupakan sebuah kerajaan besar di Lombok yang banyak dikenal, baik dipulau Lombok maupun diluar daerah. Nama Selaparang hingga sekarang juga masih tetap lestari menjadi nama Desa Selaparang, tempat Makam Selaparang berada. Kompleks Makam Selaparangatau masyarakat setempat menyebut Makam Keramat Raja Selaparang, memiliki fungsi sosial sebagai tempat berziarah masyarakat, tertama pada saat musim keberangkatan jemaah Haji ke Mekkah, melakukan ritual hiziban bersama, dan tempat masyarakat lombok berwisaata sekaligus makan bersam. Tradisi ini masih tetap berlanjut hingga sekarang. Disana dianggap makam yang penuh dengan mitos-mitos seperti meminta jodoh dll. Biasanya makam selaparang ramai dikunjungi pada musim haji, musim kelulusan anak Madrasah maupun sekolah negeri sampai dengan anak perkuliahan.

\section{G. Masjid Kuno Bayan Beleq}

Masjid Bayan Beleq merupakan masjid yang tertua di Pulau Lombok atau yang dikenal dengan Masjid Wetu Telu yang berada di Desa Bayan, Kecamatan Bayan, Kabupaten Lombok Utara. Masjid Bayan Beleq di bangun oleh Gaus Abdul Razaq. Bentuknya yang sederhana meimiliki banyak makna dan memiliki keistimewaan tersendiri. Masjid Bayan Beleq menjadi gerbang masuknya Islam di Pulau Lombok yang berdiri pada abad ke-17. Baangunan Masjid Bayan Beleq disusun dari bilah-bilah bambu, fondasi lantainya terbuat dari batu-batu kali dan lantainya terbuat dari tanah liat. Masjid Bayan Beleq memiliki ukuran 9 x 9 meter.

Masjid Bayan Beleq tidak digunakan seperti masjid pada biasanya, namun Masjid Bayan Beleq di gunakakan oleh masyarakt sekitar pada acar-acara tertentu, seperti perayaan Maulid Nabi muhammad. Perayaan hari kelahiran Nabi Muhammad ini diadakan selama dua (2) hari. Perayaan tersebut akan banyak di ikuti oleh masyarakat Desa bayan dan Khususnya Masyarakat Lombok, selain masyarakat lokal yang mengikuti rangkaian perayaan Maulid Nabi muhammad, bahkan banyak juga Wisatawan Mancannegara (WISMAN) yang tertarik untuk mengikuti acara adat tersebut. Wisatawan yang mengikuti perayaan Maulid Nabi Muhammad harus menggunakan pakaian adat yang sudah di tentukan dalam aturan adat istiadat. Masjid Bayan Beleq ini merupakan Masjid Kuno yang harus di pelihara karena salah satu warisan budaya, selain berkontribusi sebagai pintu gerbang masuknya agam Islam, Masjid Bayan Belek juga menjadi ikon pariwisata Lombok Utara.

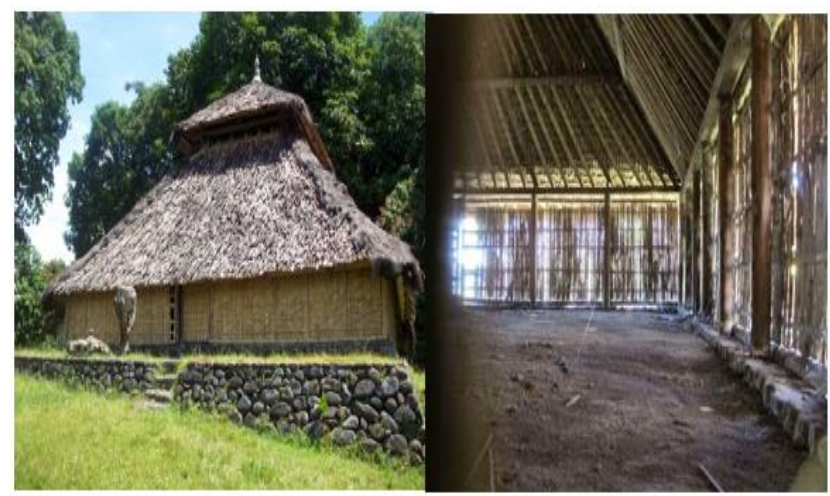

Gambar : Masjid Kuno Bayan Beleq

\section{H. Upacara Adat Ngayuh Ayu}

Acara tersebut diberi nama Upacara Adat Ngayu-ayu, yang diselenggarakanoleh masyarakat sekitar. Acaranya diadakan setiap 3 tahun sekali dan sudah turun temurun sejak lebih dari 600 tahun yang lalu.Ritual AyuNgayu merupakan bentuk rasa syukur kehadirat Tuhan Yang Maha Esa atas diberikan kelimpahan hasil bumi, terhindar dari bencana, dan masyarakat diharapkan terhindar dari penyakit-penyakit yang

http://ejurnal.binawakya.or.id/index.php/MBI 
konon di zaman dahulu sering dialami oleh masyarakat setempat.

Prosesi acara ritual Ngayu Ayu ini berlangsung selamaduahari. Di hari pertama, pembuatan makananyang bahan nya dari ketan dan santan kelapa, prosesnya juga membutuhkan waktu yang cukup lama sekitar dua jam. Ketan yang sudah tercampur dengan santan didiamkan selama beberapa menit untuk persiapan pembakaran. Kentan yang sudah jadi didiamkan selama satu malam di rumah ketua warga yang mengikuti upacara adat Ngayu ayu. Keesokan harinya dikumpulkan menjadi satu di rumah ketua Adat.

Pelaksanaan upacara adat. Peserta harus menggunakan pakaian adat yaitu, sapuk dan dodot (sarung adat) bagi kaum laki-laki. Sedangkan, kaum perempun diwajibkan menggunakn pakaian adat yang disediakan di Bayan.Hari kedua dimulai dengan acara penyembelihan hewan (kambing dll) yang dilakukan oleh ketua adat dan masyarakat yang selanjutnya kepala hewan tersebut ditanam sebagai pasak bumi (pengaman) Desa Bayan dari bala bencana.

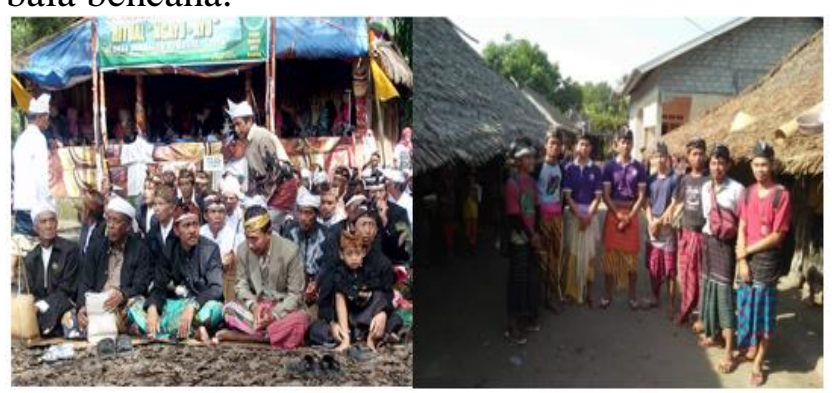

Gambar: Upacara Adat Ngayu Ayu

Kemudian dagingnya dimasak di tempat dengan cara memanggang setempat untuk disajikan dan disantap bersama-sama yang dalam istilah Bahasa Sasaknya adalag "Begibung". Setelah itu, diadakan Ritual Mafakin, dimana ritual ini para Ketua Adat membacakan bacaanbacaan selama prosesi penurunan bibit padi merah (pade abang) dari lembang sampai proses penyemaian. Selanjutnya diadakan perang topat. Setelah prosesi di atas, masyarakat mengitari makam adat sebanyak sembilan kali putaran masing-masing ketua adat atau yang diwakilkan oleh anaknya menggendong air dari tujuh sumber http://ejurnal.binawakya.or.id/index.php/MBI mata air sebelum dikumpulkan menjadi satu di dalam makam.

\subsection{Ketersediaan Komponen Produk Wisata Syariah Di Pulau Lombok}

\section{A. Amenitas (Amenities)}

Amenitas atau amenities merupakan salah satu komponen pariwisata yang harus tersedia dalam mendukung jalannya sebuah aktivitas pariwisata di suatu daerah. Menurut Kurniansah (2018) mengemukakan bahwa amenitas berkaitan dengan ketersediaan sarana akomodasi untuk menginap serta restoran atau warung untuk makan dan minum. Kebutuhan lain yang mungkin juga diinginkan dan diperlukan oleh wisatawan, seperti toilet umum, rest area, tempat parkir, klinik kesehatan, dan sarana ibadah sebaiknya juga tersedia di sebuah destinasi.

Keberadaan akomodasi hotel dan restoran dalam mendukung jalannya pariwisata syariah di Lombok telah tersedia dan memadai. Peraturan Gubernur NTB Nomor 51 Tahun 2015 Tentang Wisata Halal Pasal 1 Nomor 11 dan 12, telah ditentukan tentang hotel syariah yaitu adalah penggolongan untuk usaha hotel syariah yang dinilai memenuhi seluruh kriteria Usaha Hotel Syariah yang diperlukan untuk melayani kebutuhan minimal wisatawan muslim, kriteria terebut terkait dengan ketentuan dan persyaratan minimal tentang produk, pelayanan, dan pengelolaan yang wajib dipenuhi dan dilaksanakan oleh Pengusaha Hotel sehingga dapat diakui sebagai Usaha Hotel Syariah dan memperoleh Sertifikat Usaha Hotel Syariah.

Secara umum hotel yang melabelkan hotel syariah di Lombok belumlah terlalu banyak, salah satu hotel syariah di Lombok yaitu Grand Madani Hotel yang berlokasi di Kota Mataram.

\section{B. Aksesibilitas (Accessibility)}

Aksesibilitas atau Accessibility merupakan komponen selanjutnya untuk mendukung keberadaan daya tarik wisata syariah di Lombok yaitu tersedianya alat trasnportasi (Mini Bus, Bus, Motor, Bandara, dan Kapal Laut) dan kondisi jalan. Secara umum ketersediaan aksesibilitas untuk menuju daya tarik wisata

Vol.13 No.12 Juli 2019

\section{Open Journal Systems}


syariah di Pulau Lombok dalam kondisi baik. Hal ini dibuktikan dengan tersedianya alat transportasi seperti Mini Bus, Bus, Motor, Bandara, dan Kapal Laut.

Kondisi jalan menuju daya tarik wisata Syariah di Pulau Lombok secara umum dalam kondisi baik serta telah tersedianya alat transportasi yang telah memadai dan telah didukung oleh pelayanan taksi konvensiol maupun taksi online seperti Grab dan GoJek. Ketersedian alat trasnportasi tersebut memberikan kemudahan kepada wisatawan untuk berkunjung.

\section{Pelayanan pendukung yang terorganisasi (Ancillary)}

Dalam mendukung jalannya aktifitas di daya tarik wisata syariah di Pualu, perlu ada sebuah organisasi antara pemerintah maupun pihak swasta yang khusus untuk membuat kebijakan, mengatur dan mengelola sebuah daya tarik wisata. Dengan adanya keterlibatan dari pemerintah serta swasta tersebut, tentu bertujuan untuk menjaga serta mengelola secara keberlanjutan. Menurut Inskeep dalam Kurniansah (2018) Ancillary Service merupakan pelayanan yang diberikan oleh destinasi kepada wisatawan dan industri, berupa pemasaran, pengembangan dan koordinasi antar komponen destinasi. Fungsi ancillary service ini dilakukan oleh organisasi/instansi pemerintah, swasta maupun gabungan instansi pemerintah dan swasta.

Dalam pengelolaan serta pengembangan daya tarik wisata syariah, di atur langsung oleh Dinas Pariwisata di Kabupaten masing-masing seperti Dinas Pariwisata Kabupaten Lombok Utara, Mataram, Lombok Tengah, Lombok Timur dan Lombok Barat dengan berkoordinasi dengan Dinas Pariwisata Provinsi NTB. Peran dari masing-masing Dinas Pariwisata tersebut dalam mengelola dan mengembangkan daya tarik wisata syariah, sajuah ini sudah cukup optimal. Pemerintah telah melakukan berbagai upaya dalam menata dan mengembangkan daya tarik wisata syariah, termaksud upaya melakukan promosi, sadar wisata yang disosialisasikan kepada masyarakat serta menatapkan peraturan mengenai pengutipan retribusi memasuki tempat wisata. Peran lain dari pemerintah yaitu mengupayakan disetiap daya tarik wisata syariah di suatu desa membentuk salah satu kelompok sadar wisata (Pokdarwis) untuk mengelola daya tarik wisata syariah di desa masing-masing.

\section{PENUTUP \\ Kesimpulan}

Berdasarkan hasil pembaahasan yang diuraikan sebelumnya dapat disimpulkan bahwa pulau lombok memiliki potensi daya tark wisata syariah yang beragam mulai dari daya tarik wisata alam dan budaya. Daya tarik wisata tersebut antara lain: Taman Makam Bintaro, Masjid Islamic Center, Pantai Tanjung Karang, Festival Ngejot, Acara Adat Tiu Jantuk, Makam Selaparang, Masjid Kuno Bayan Beleq dan Upacara Adat Ngayuh Ayu.

Keberadaan potensi wisata tersebut tentu telah didukung oleh ketersediaannya komponen produk wisata syariah di pulau Lombok yaitu hotel syariah (Hotel Grand Madani Lombok), Kondisi Jalan sudah baik, dan didukung pelayanan taksi konvensi dan online yaitu Gojek dan Grab. Serta pelayanan pendukung yang terorganisasi seperti Dinas Pariwisata Kabupaten Lombok Utara, Mataram, Lombok Tengah, Lombok Timur dan Lombok Barat dengan berkoordinasi dengan Dinas Pariwisata Provinsi NTB. Peran lain dari pemerintah yaitu mengupayakan disetiap daya tarik wisata syariah di suatu desa membentuk salah satu kelompok sadar wisata (Pokdarwis) untuk mengelola daya tarik wisata syariah di desa masing-masing.

\section{Saran}

Berdasarkan kesimpulan diatas, penulis dapat memberikan saran untuk meningkatkan kualitas dari wisata syariah di Pulau Lombok yaitu :

1. Menyediakan fasilitas pendukung di setiap lokasi daya tarik wisata seperti tempat beribadah, rumah makan, toilet. Dll

2. Meningkatan kualitas sumber daya manusia yang kompeten di bidang pariwisata agar masyarakat lebih siap dalam mengelola

http://ejurnal.binawakya.or.id/index.php/MBI 
potensi yang ada serta dapat memberikan pelayanan yang baik kepada para wisatawan.

\section{DAFTAR PUSTAKA}

[1] BPS Lombok Barat. 2016. Kabupaten Lombok Barat Dalam Angka 2016. Lombok Barat: CV. Maharani.

[2] Cooper, Chris. Dkk. 1993. Tourism Principles \& Practice. England: Longman Group.

[3] Dinas Pariwisata Kota Mataram. 2017. Angka Kunjungan Wisatawan Kota Mataram Perbulan Tahun 2016. Tersedia Pada:

http://dispar.mataramkota.go.id/detail/post/9 8.Diakses Tanggal: 2/06/2017.

[4] Kurniansah, Rizal dan Hali, Muhammad Sultan. 2018. Kajian Potensi Pariwisata Perkotaan (Urban Tourism) Sebagai Daya Tarik Wisata Kota Mataram Provinsi Nusa Tenggara Barat. Jurnal Media Bina Ilmiah. Vol 13 (2). Hal. 925-930.

[5] Pratiwi, Tika Putri. 2014. Strategi Peningkatan Pendapatan Asli Daerah, Investasi dan Pertumbuhan Ekonomi Kota Semarang Melalui MICE (Meeting, Incentive, Convention dan Exhibition). Economics Development Analysis Journal. Vol. 3, No. 1, Page 39-54.

[6] Prijadi, Rachmat dkk. 2014. Pengaruh Permukaan Jalur Pedestrian Terhadap Kepuasan dan Kenyaman Pejalan Kaki di Pusat Kota Manado. Jurnal Media Matrasain. Vol. 11, No. 1, Page 43-54.

[7] Priono, Yesser. 2012. Identifikasi Produk Wisata Pariwisata Kota (Urban Torism) Kota Pangkalan Bun Sebagai Urban Heritage Tourism. Jurnal Perspektif Arsitektur. Vol.7, No. 2, Page 72-84.

[8] Tondobala, Linda. 2012. Kelayakan Pusat Kota Manado Sebagai Destinasi Pariwisata. Jurnal Media Matrasain. Vol.9, No.3, Page 83.

[9] Trigantiarsyah, Rela dan Mulyadi, Hari. 2012. Pengembangan Produk Wisata Dengan Menggunakan Teknik Tourism Opportunity Spectrum Terhadap Keputusan http://ejurnal.binawakya.or.id/index.php/MBI
Berkunjung. Tourism and Hospitality Essentials (THE) Journal, Vol.2, No.1, page 157.

[10] Wardhani, Apriliana Dyah. 2012. Evolusi Aktual Aktivitas Urban Tourism di Kota Bandung dan Dampaknya Terhadap Pembentukan Tempat-Tempat Rekreasi. Jurnal Pembangunan Wilayah dan Kota. Vol. 8, No. 4, Page 371-382.

[11] Yoeti, Oka A. 2002. Perencanaan Strategi Pemasaran Daerah Tujuan Wisata. Jakarta: Pradnya Paramita. 
HALAMAN INI SENGAJA DIKOSONGKAN 